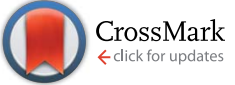

Cite this: RSC Adv., 2017, 7, 12437

Received 25th November 2016 Accepted 11th February 2017

DOI: 10.1039/c6ra27334c

rsc.li/rsc-advances

\section{Assessment of the toxicity and inflammatory effects of different-sized zinc oxide nanoparticles in 2D and 3D cell cultures}

\author{
Zhipan Wu,,$^{\mathrm{a}}$ Rongfa Guan, $\dagger^{\star a}$ Miao Tao,,$^{\mathrm{a}}$ Fei Lyu, ${ }^{\mathrm{b}}$ Guozhou Cao, ${ }^{\mathrm{c}}$ Mingqi Liu ${ }^{\mathrm{a}}$ \\ and Jianguo Gao ${ }^{d}$
}

Two-dimensional (2D) monolayer cell cultures are the most common in vitro models for mechanistic studies on the toxicity of engineered nanoparticles (NPs). However, 2D cell cultures may not accurately model the functions of three-dimensional (3D) tissues that have extensive cell-cell and cell-matrix interactions, and thus may lead to wrong experimental results. Hence, to obtain more adequate and detailed information about ZnO NP-tissue interactions, we here assess the toxicity and inflammatory effects of different-sized ZnO NPs at various concentrations on Caco-2 cells which are threedimensionally cultured in agarose gels, measuring ROS expression, pro-inflammatory cytokines, cell proliferation and death. The results showed that the significant effects of cell dimensionality to cellular responses such as inflammatory response, cytotoxicity and different modes of cell death in response to ZnO NPs treatment. Moreover, ZnO NPs induced the toxicity of 2D and 3D cells in different sizedependent manners. This study revealed that the nanotoxicity conclusions obtained from the 2D cell model might overestimate the toxic effects of ZnO NPs. There is a more realistic mechanism study of nanoparticle-induced toxicity in the 3D cell model, which acts as an intermediate stage bridging in vitro $2 \mathrm{D}$ and in vivo models.

\section{Introduction}

Zinc oxide nanoparticles (ZnO NPs) have been used in the field of catalysis, sunscreen cosmetics, paint materials, and food packaging materials because of their unique optical, electrical, and thermal performance. ${ }^{\mathbf{1 , 2}}$ Nanoparticles have a strong influence on the way they interact with biological components, ${ }^{3}$ and it raises a real concern about the risk to human health from the inevitable exposure to NPs. ${ }^{4}$ The inconsistencies among culture dish assessments, animal trials, and consumers' perceived experience after exposure to these NPs constitute burden for defining the biological effects and underlying toxic mechanisms of NPs. ${ }^{5} \mathrm{ZnO}$ NPs have good antimicrobial activity that can be utilized as agents to prevent harmful microorganism growth in food. ${ }^{6}$

\footnotetext{
${ }^{a}$ Zhejiang Provincial Key Laboratory of Biometrology and Inspection \& Quarantine, College of Life Sciences, China Jiliang University, Xueyuan Road 258, Hangzhou 310018, China. E-mail: wuzhipanjl@126.com; taomfood@126.com; mqliu524@163. com; Rongfaguan@163.com; Fax: +86-571-8691449

${ }^{b}$ Ocean College, Zhejiang University of Technology, Hangzhou 310014, China. E-mail: lvfei_zju@163.com

'Ningbo Entry-Exit Inspection and Quarantine Technology Center, Ningbo 315000, China.E-mail: caogz@nbciq.gov.cn

${ }^{d}$ Inspection and Quarantine Center of Shandong Exit \& Entry Inspection and Quarantine Bureau, Qingdao 266002, Shandong province, China. E-mail: china. gjg@163.com

$\dagger$ Equal contributors.
}

However, the use of ZnO NPs as food additive is limited by the perceived high toxicity of ZnO NPs in many earlier toxicity studies. ${ }^{6-9}$ Two-dimensional (2D) monolayer cell model have a very low anatomical and physiological relevance, while they remain the predominant in vitro model for numerous nanotoxicity studies. ${ }^{\mathbf{1 0} 11}$ However, cells lose their original tissue organization, polarity, and protein-protein interactions in the case of $2 \mathrm{D}$ cell culture on a flat substrate, which in turn significantly limits their ability to recapitulate the appropriate level of in vivo cellular responses. ${ }^{12}$ Due to the absence of cell-cell and cellmatrix interactions, tests based on in vitro $2 \mathrm{D}$ cell culture model do not accurately predict in vivo toxicity and other biological effects despite of providing valuable and important information. ${ }^{13,14}$ Therefore, a more tissue-like, physiologically relevant model which can mimic the interactions between biological systems and NMs is most needed.

Virtually all cells reside in a three-dimensional (3D) milieu of the body and sophisticated interactions with 3D organized extracellular matrix (ECM) proteins and neighboring cells is critical for the phenotype and function of individual cells. ${ }^{15,16}$ However, organ culture (ex vivo) to obtain and scale up the specimen for multiparametric studies is generally more difficult. ${ }^{17}$ 3D cell culture model such as microtissue spheroid which emulates the complex in vivo cellular organization is easier to be established in a laboratory than organ culture. Previous study reported that the enhanced specific protein secreting function 
of granular epithelial cells could only be observed when they formed a 3D organized acinus structure. ${ }^{18,19}$ Additionally, an important reason of expanding cell toxicity assays from $2 \mathrm{D}$ to $3 \mathrm{D}$ cultures is a large discrepancy in toxicity results between in vitro $2 \mathrm{D}$ cell culture and in vivo animal models. ${ }^{20}$ For example, 2D cell models were previously reported to showed high cytotoxic effects on toxicity testing of magnetic NPs, ${ }^{21}$ carbon nanotubes, ${ }^{22}$ and fullerenes, ${ }^{23}$ while no adverse effects were observed in animal models. ${ }^{24-26}$ Thus, 3D cell culture model is a promising and valuable approach to explore the complex interactions between cells and NPs.

$3 \mathrm{D}$ cell culture models were previously reported to bridge the gap between $2 \mathrm{D}$ cell culture and in vivo models. ${ }^{27}$ For instance, these cell-to-cell and cell-to-matrix interactions could be better mimicked in the case of 3D cell model. ${ }^{28}$ Cellular polarity could be induce in cellular microenvironment of a 3D cell model, and then in favor of tissue organization and the directed secretion of products. ${ }^{29}$ Obviously, these examples indicated that $3 \mathrm{D}$ cell culture models could be as a more valid and realistic for nanotoxicity studies. One study has reported the in vitro $\mathrm{ZnO}$ NPs toxicity testing using $2 \mathrm{D}$ cell culture, ${ }^{30}$ so it will be very important to use 3D cell model for the toxicity assessment of $\mathrm{ZnO}$ NPs and compare the results with 2D cell culture.

In this study, the assessment of toxicity and inflammatory effects of different sized ZnO NPs at various concentrations $(0,10$, $25,50,75$, or $100 \mu \mathrm{g} \mathrm{mL}{ }^{-1}$ ) on Caco-2 cells, three-dimensionally cultured in agarose gels, was evaluated by measuring ROS expression, pro-inflammatory cytokines, cell proliferation and death.

\section{Materials and methods}

\subsection{Characterization of ZnO NPs}

A stock suspension of ZnO NPs (final concentration, $400 \mu \mathrm{g}$ $\mathrm{mL}^{-1}$; Shanghai Jingchun Biochemical Technology Company, Shanghai, China) was prepared in phosphate-buffered saline (PBS, Sigma, USA). Prior to each treatment, the suspension was ultrasonicated before exposure (amplitude, 100\%; pulse, $5 \mathrm{~s} / 10 \mathrm{~s}$; $2 \mathrm{~min}$ ) and diluted to prepare the desired $\mathrm{ZnO} \mathrm{NP}$ concentrations $\left(10,25,50,75\right.$, and $\left.100 \mu \mathrm{g} \mathrm{mL} \mathrm{m}^{-1}\right)$ in serum-free medium without L-glutamine and antibiotics. Particle morphology, size, and agglomeration states were characterized via transmission electron microscopy (TEM, JEOL JEM-2100, JEOL Ltd., Tokyo, Japan). Samples for TEM analysis were prepared through anhydrous ethanol ultrasonic dispersion onto standard holey carbon-coated copper grids, which were then air-dried at room temperature. The intensity and size of the particles were analyzed using a Malvern Zetasizer (Worcestershire, UK).

\subsection{Cell culture}

Cell preparation. Caco- 2 cells were derived from a human epithelial colorectal adenocarcinoma (The Type Culture Collection of the Chinese Academy of Sciences, Shanghai, China). The cells were cultured in Dulbecco's modified Eagle's medium (DMEM, Gibco BRL, Gaitherburg, MD, USA) supplemented with $10 \%$ fetal bovine serum (FBS, Hyclone Laboratories, Inc., USA) and $1 \%$ antibiotics (Sigma, USA), maintained at $37{ }^{\circ} \mathrm{C}$ in an atmosphere of $95 \%$ air and $5 \% \mathrm{CO}_{2}$ in $75 \mathrm{~cm}^{2}$ flasks, and then sub-cultured once every 3 days at $80 \%$ confluence.

2D cell culture. Caco- 2 cells were isolated using $0.05 \%$ Trypsin-EDTA (Sigma, USA) and centrifuged at $2000 \mathrm{rpm}$ for 2 min. Isolated cells were seeded at 24 -well and 96-well plate according to the experimental design. The cells were then cultured using DMEM supplemented with 10\% FBS, 1\% antibiotics (100 IU mL $\mathrm{mL}^{-1}$ penicillin, $100 \mu \mathrm{g} \mathrm{mL}{ }^{-1}$ streptomycin), maintained at $37{ }^{\circ} \mathrm{C}$ in an atmosphere of $95 \%$ air with $5 \% \mathrm{CO}_{2}$. The medium was replaced every 3-4 days. All of the experiments were performed on logarithmically growing cells. The prepared cells were exposed to various $\mathrm{ZnO}$ NP concentrations $(0,10,25$, 50,75 , or $100 \mu \mathrm{g} \mathrm{mL} \mathrm{m}^{-1}$ ).

3D cell culture. Caco- 2 cells were isolated as previously described. The cells of seeding density $2 \times 10^{5}$ cells per $\mathrm{mL}$, were then immobilized in a $1 \%$ agarose gel casted by using $3 \mathrm{D}$ Petri dish (Sigma, USA), which contained 96 small wells. A portion of the cell suspension containing $1 \times 10^{5}$ cells $/ 500 \mu \mathrm{L}$ was added to an equal volume of sterilized, and molten $\left(37^{\circ} \mathrm{C}\right)$, $2 \%\left(\mathrm{w} / \mathrm{v}\right.$ ) agarose in PBS solution (Sigma, USA)..$^{31,32}$ A $500 \mu \mathrm{L}$ aliquot of the mixture was then loaded into a 24 -well plate fitted into the 3D Petri dish and kept at room temperature for $30 \mathrm{~min}$ to allow the gel to solidify. The cells were then cultured using DMEM supplemented with $10 \%$ FBS, and $1 \%$ antibiotics maintained at $37{ }^{\circ} \mathrm{C}$ in an atmosphere of $95 \%$ air with $5 \% \mathrm{CO}_{2}$. The medium was replaced every 3-4 days. All of the experiments were performed on logarithmically growing cells. The prepared cells were exposed to various ZnO NP concentrations (0, 10, 25, 50,75 , or $100 \mu \mathrm{g} \mathrm{mL}^{-1}$ ). Agarose is acts as a scaffold for cell culture, so that $3 \mathrm{D}$ cell culture has possibility. Cell matrix provides cell culture environment a third dimension. There are several main types of cell matrix, including hydrogel scaffold from natural materials, such as extracellular matrix collagen; second type of cell matrix is synthetic hydrogel, including bionic peptide, sometimes they can strengthen the combination of integrin. Other types of artificial scaffold are plastic from tissue culture, and even biodegradable plastics.

\subsection{Characterization of Caco- 2 cells}

Caco-2 cells were cultured on $2 \mathrm{D}$ and $3 \mathrm{D}$ microstructured substrates. Microstructures were generated by XDS-100 invert microscope (Shanghai Cai Kang Optical Instrument Company, China). Using inverted microscope to observe the morphology of Caco- 2 cells under 2D and 3D circumstances.

\subsection{ROS assay}

Intracellular reactive oxidative stress (ROS) expression level was detected and measured, using the redox sensitive CellROX orange reagent that fluoresces brightly when exposed to ROS. Caco- 2 cells were seeded in 96-well plate format (2D) or agarose gel cultured format (3D) as previously described. The cells were treated with three sizes of ZnO NPs at various concentrations ( 0 , $10,25,50,75$, or $100 \mu \mathrm{g} \mathrm{mL}{ }^{-1}$ ) for 6 and $12 \mathrm{~h}$. At the end of the treated time, CellROX orange reagent (Reactive Oxygen Species Assay Kit, Beyotime Company, Shanghai, China) were added 
directly to every well and then, the samples were incubated at $37{ }^{\circ} \mathrm{C}$ and protected from light for $30 \mathrm{~min}$. Thereafter, the staining solution was removed and the cells was washed three times using ice-cold PBS. The samples were observed under a fluorescence microscope (Nikon Eclipse Ti, Nikon, Shinjuku, Tokyo, Japan) and the data were expressed as ROS-positive cells.

\subsection{Measurement of pro-inflammatory cytokines}

Interleukin-8 (IL-8) and Interleukin-1 $\beta$ (IL-1 $\beta$ ) are proinflammatory cytokines correlated with inflammatory potential of particles. ${ }^{33} 2 \mathrm{D}$ and $3 \mathrm{D}$ cells were treated with $24 \mathrm{~nm}$, $56 \mathrm{~nm}$ and $87 \mathrm{~nm} \mathrm{ZnO}$ NPs (the average particle size) at various concentrations $\left(0,10,25,50,75\right.$, or $\left.100 \mu \mathrm{g} \mathrm{mL} \mathrm{m}^{-1}\right)$ for 12 and $24 \mathrm{~h}$. At the end of the treated time, 2D and 3D cells were trypsinized by trypsin-EDTA and the trypsinized cells were neutralized with completed DMEM. The cells mixture was centrifuged to remove supernatant, then washed and centrifuged twice using $1 \times$ PBS to remove all traces of the medium. The cell pellet was sonicated at $300 \mathrm{~W}$ for $10 \mathrm{~s}$ ( 3 cycles) to obtain lysates, which were then centrifuged at $1000 \mathrm{rpm}$ for $10 \mathrm{~min}$ to obtain the supernatant. We measured IL-8 protein levels and IL-1 $\beta$ in the supernatant of $2 \mathrm{D}$ and $3 \mathrm{D}$ cells according to the instruction manual (R\&D Systems).

\subsection{Cell proliferation}

DNA quantification was performed to assess cell proliferation using the Quant-iT PicoGreen dsDNA reagent and kit (Molecular Proves, Eugene, OR, USA). DNA quantification was measured via fluorescent expression of PicoGreen dye binding to cellular nucleic acids assay. Caco- 2 cells were seeded in 96-well plate format (2D) or agarose gel cultured format (3D) as previously described. The cells were treated with $24 \mathrm{~nm}$ ZnO NPs (the average particle size) at various concentrations $(0,10,25,50,75$, or $100 \mu \mathrm{g} \mathrm{mL}{ }^{-1}$ ) for 12 and $24 \mathrm{~h}$. Then, in the 3D agarose gel cultured model, the cells encapsulated in agarose gel were directly digested in papain buffer without any prior extraction. The cell samples were placed in $1.5 \mathrm{~mL}$ sterile Eppendorf tubes at $37{ }^{\circ} \mathrm{C}$ for $5 \mathrm{~min}$ with $1 \mathrm{~mL}$ of papain digestion buffer $(100 \mathrm{mM}$ $\mathrm{Na}_{2} \mathrm{HPO}_{4}, 5 \mathrm{mM}$ L-cysteine, $5 \mathrm{mM}$ EDTA, pH 7.5) containing 125 $\mu \mathrm{g} \mathrm{mL}^{-1}$ papain type III. Following digestion, the samples were heated to $60^{\circ} \mathrm{C}$ for $10 \mathrm{~min}$ to melt the agarose. In $2 \mathrm{D}$ cell model, the cells were digested as in the previously described 3D cultured model. Then the samples were centrifuged at $5000 \mathrm{~g}$ for $2 \mathrm{~min}$ at room temperature. Exactly $100 \mu \mathrm{L}$ of the supernatant and $100 \mu \mathrm{L}$ of PicoGreen fluorescence reagent $(1: 200$ in Tris-EDTA buffer, Invitrogen Co., NY, USA) were added to each well of 96-well plate, and the mixture was mixed thoroughly. Fluorescence was measured in a multi-detection reader (Synergy HT BioTek, Winooski, VT, USA). DNA standards were prepared using the same procedure and sample values were calculated using the known DNA standards.

\subsection{Modes of cell death}

An AnnexinV-FITC/Propidium Iodide (PI) detection kit was used to quantify different modes of cell death. ${ }^{34} 2 \mathrm{D}$ and $3 \mathrm{D}$ cells were treated with $24 \mathrm{~nm}, 56 \mathrm{~nm}$ and $87 \mathrm{~nm}$ ZnO NPs (the average particle size) at various concentrations $(0,10,25,50,75$, or 100 $\mu \mathrm{g} \mathrm{mL}^{-1}$ ) for $24 \mathrm{~h}$. After $24 \mathrm{~h}$ of incubation, all treated $2 \mathrm{D}$ and $3 \mathrm{D}$ cells were trypsinized by trypsin-EDTA at $37^{\circ} \mathrm{C}$. The trypsinized cells were then neutralized with completed DMEM, collected via centrifugation, washed with $1 \times$ PBS and subsequently resuspended in $100 \mu \mathrm{L}$ of binding buffer. Exactly $5 \mu \mathrm{L}$ of AnnexinV-FITC and $10 \mu \mathrm{L}$ of PI solution were added into the cell suspension. After $15 \mathrm{~min}$ of incubation at room temperature in the dark according to the manufacturer's instructions, cell apoptosis was immediately analyzed by using a flow cytometer (Partech GmbH, Germany).

\section{Results}

\subsection{Characterization of ZnO NPs}

TEM was conducted to investigate the morphology of the $\mathrm{ZnO}$ NPs, and size distribution was assessed using a Malvern instrument. Fig. 1 shows representative TEM images of the ZnO NPs. The ZnO NPs showed the following average particle diameters: (a) $24.49 \pm 2.54 \mathrm{~nm}$, (b) $56.11 \pm 8.56 \mathrm{~nm}$, and (c) $87.26 \pm 13.47 \mathrm{~nm}$. Fig. 1d-f showed nanoparticles of different sizes. Thus, 24, 56, and $87 \mathrm{~nm} \mathrm{ZnO} \mathrm{NPs} \mathrm{were} \mathrm{used} \mathrm{in} \mathrm{the}$ following test system.

\subsection{Characterization of Caco-2 cells}

As Fig. 2a and b show, Caco-2 cells in $2 \mathrm{D}$ culture plate, form a cell model of monolayer, firm, adherent, and present fusiform or polygonal; Caco-2 cells in 3D culture, form larger and spherical cell masses. After $10 \mu \mathrm{g} \mathrm{mL}{ }^{-1} \mathrm{ZnO}$ NPs (24 nm average particle size) affecting $2 \mathrm{D}$ and $3 \mathrm{D}$ cells, compared with the control groups (Fig. 2a and b), 2D cellular morphology has good adherence, no obvious change, but refractive index becomes worse, gap bigger, some cells become smaller and more round; the form of $3 \mathrm{D}$ cells almost no change (Fig. 2c and d). As shown in Fig. 2e and $\mathrm{f}$, when the virus concentration increased to $75 \mu \mathrm{g}$ $\mathrm{mL}^{-1}$, in the $2 \mathrm{D}$ model, can discover black and conglobatus ZnO NPs (24 nm average particle size), necrosis in morphology, different degree of crushing, lower adherence, "dirty", populations decrease; 3D cells still does not have obvious changes in morphology, but the cell clusters are smaller.

\subsection{ROS expression}

ROS-positive cells are defined as cells with measured ROS expression levels higher than a pre-determined fluorescence threshold value. As shown in Fig. 3, significant increased ROS levels was observed in 2D format, but not for Caco- 2 cells in $3 \mathrm{D}$ culture after both $6 \mathrm{~h}$ and $12 \mathrm{~h}$ of ZnO NPs exposure. Caco-2 cells cultured in $3 \mathrm{D}$ possessed a higher basal level of ROS expression as compared to the cells in 2D at low concentrations (around $10 \mu \mathrm{g} \mathrm{mL}{ }^{-1} \mathrm{ZnO} \mathrm{NPs}$ ), even the untreated 3D control. Surprisingly, the difference in endogenous ROS levels of $2 \mathrm{D}$ cells is much lower $(2.9 \%, 3.2 \%$ and $3.3 \%$, control groups at $6 \mathrm{~h}$ ) and not as significant $(p>0.25)$ as the one observed in $3 \mathrm{D}$ cell model (Fig. 3a, c and e). $24 \mathrm{~nm}$ ZnO NPs (the average particle size) treatment increased the highest percentage of oxidative stressed cells compared to $56 \mathrm{~nm}$ and $87 \mathrm{~nm} \mathrm{ZnO} \mathrm{NPs} \mathrm{(the}$ 


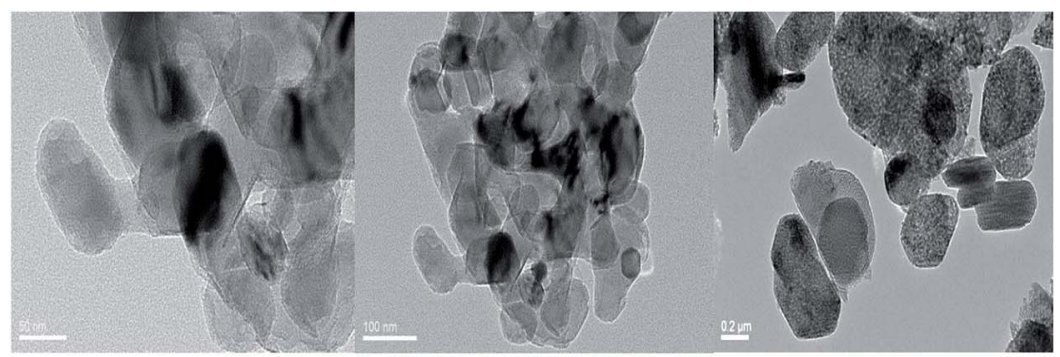

(a)
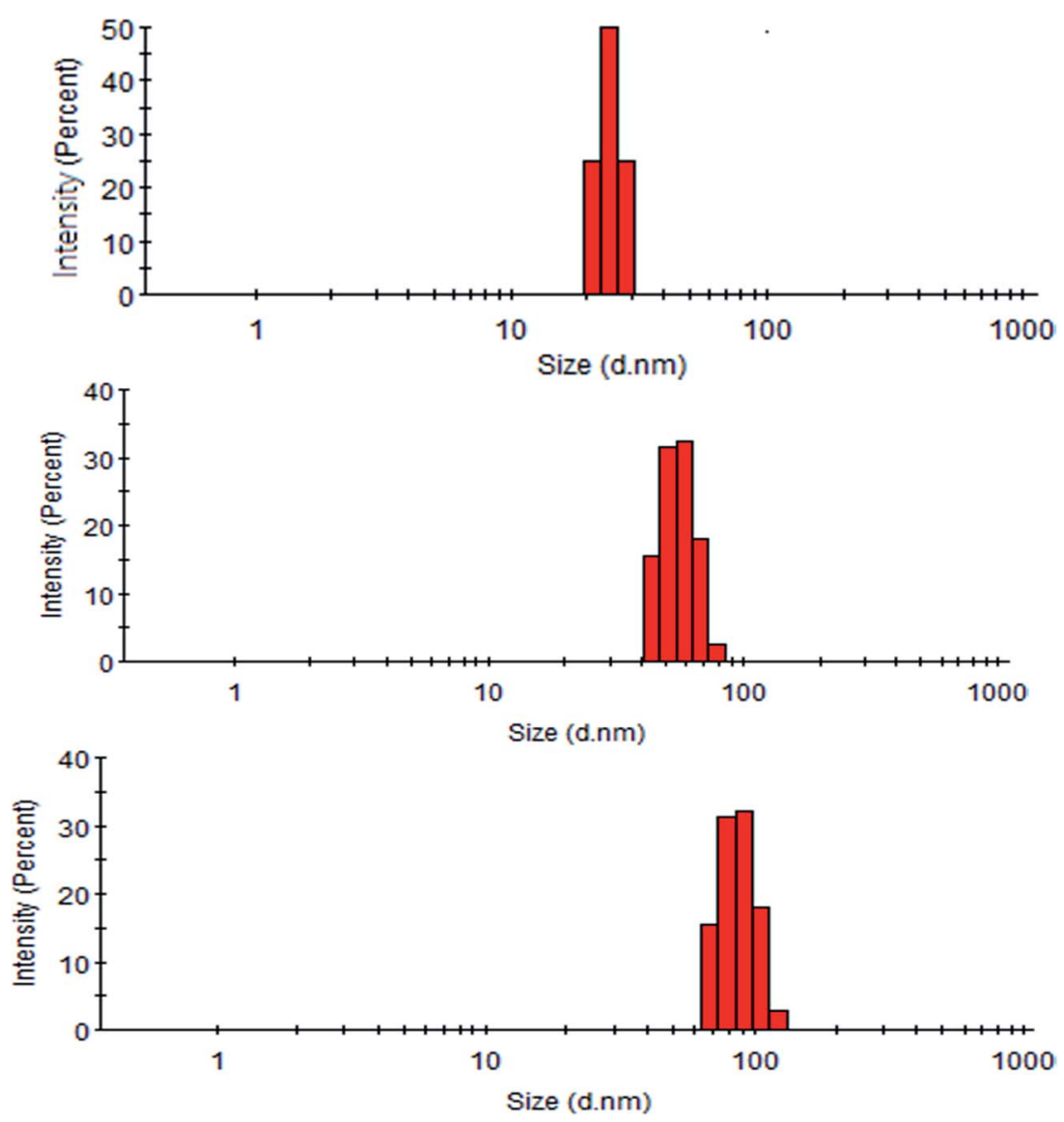

(d) (e)

(f)

Fig. 1 Microscopy characterizations of ZnO NPs. TEM images of an average: (a) $24 \mathrm{~nm}$ ZnO NPs (the average particle size), (b) $56 \mathrm{~nm}$ ZnO NPs (the average particle size), and (c) $87 \mathrm{~nm}$ ZnO NPs (the average particle size). Ranges: (d) 20-30 nm for a nanoparticle, (e) 40-70 nm for a nanoparticle, and (f) 70-100 nm for a nanoparticle. TEM scale bars: (a) $50 \mathrm{~nm}$, (b) $100 \mathrm{~nm}$, and (c) $0.2 \mu \mathrm{m}$.

average particle size) in 2D cell model after $6 \mathrm{~h}$ and $12 \mathrm{~h}$ exposure, and in 3D culture after $12 \mathrm{~h}$ exposure (Fig. $3 \mathrm{~b}$ and $\mathrm{f}$ ).

\subsection{Pro-inflammatory cytokines}

Fig. 4 showed that ZnO NPs trigger differential expression of IL8 and IL-1 $\beta$ between in 2D and 3D cell model. In this study, the total protein amount averagely was $74 \mu \mathrm{g} / 10^{5}$ cells. After $12 \mathrm{~h}$ of high concentrations of ZnO NPs (above $50 \mu \mathrm{g} \mathrm{mL}^{-1} \mathrm{ZnO} \mathrm{NPs}$ ) treatment, the levels of IL-8 and IL- $1 \beta$ protein in the supernatant were significantly increased in $2 \mathrm{D}$ and $3 \mathrm{D}$ cell model except 2D cells for IL-8. We observed that More than a 5-fold and 9-fold increase of IL-8 and IL-1 $\beta$ protein, respectively, were induced by $100 \mu \mathrm{g} \mathrm{mL}{ }^{-1}$ of $24 \mathrm{~nm}$ ZnO NPs (the average particle size) in 3D cell model, but less in 2D cell culture after $12 \mathrm{~h}$ of exposure (Fig. 4a and e). $24 \mathrm{~nm}$ ZnO NPs (the average particle size) treatment increased higher levels of IL-8 and IL-1 $\beta$ than $87 \mathrm{~nm}$ ZnO NPs in 3D cell model, but no similar result was observed in 2D cell model after $12 \mathrm{~h}$ exposure (Fig. $4 \mathrm{a}, \mathrm{c}$, e and $\mathrm{h}$ ). ZnO NMs induced severe inflammatory responses to in $3 \mathrm{D}$ cell format after $12 \mathrm{~h}$ of exposure, while it did not cause a significant increase of ROS-positive cells at the same time point (Fig. 3b, $\mathrm{d}$ and $\mathrm{f}$ ). These results implied that ZnO NPs could induce an 
(a)

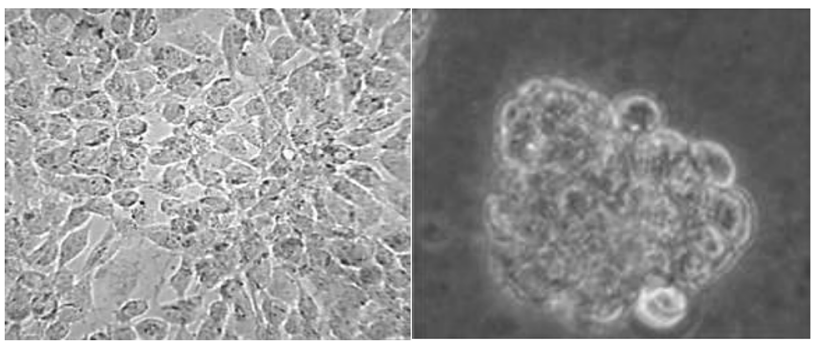

(c)

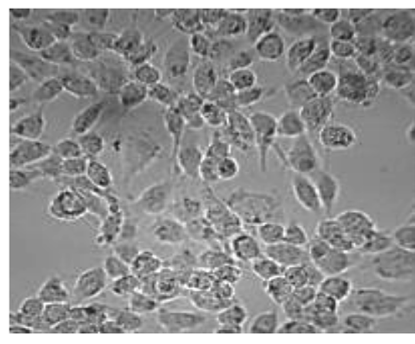

(e)

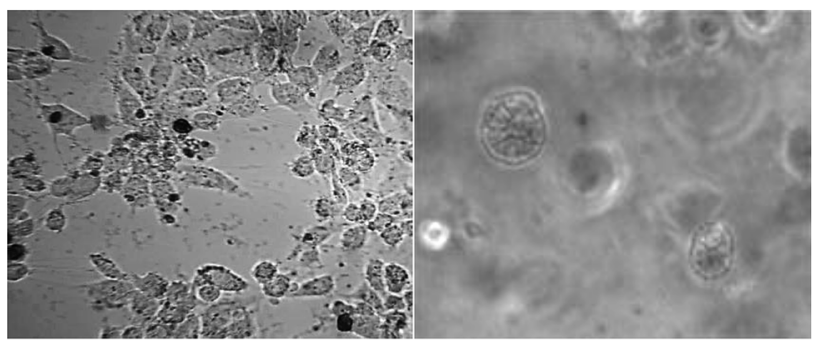

Fig. 2 Microscopy characterizations of Caco-2 cells under 2D and 3D circumstances. (a) Normal Caco-2 cells at 2D cell culture, (b) normal Caco- 2 cells at 3D cell culture, (c) after $10 \mu \mathrm{g} \mathrm{mL}{ }^{-1} \mathrm{ZnO}$ NPs $(24 \mathrm{~nm}$ average particle size) affecting $12 \mathrm{~h}, \mathrm{Caco}-2$ cells at 2D cell culture, (d) after $10 \mu \mathrm{g} \mathrm{mL}^{-1} \mathrm{ZnO}$ NPs (24 nm average particle size) affecting $12 \mathrm{~h}$, Caco- 2 cells at 3D cell culture, (e) after $75 \mu \mathrm{g} \mathrm{mL}^{-1} \mathrm{ZnO}$ NPs $(24 \mathrm{~nm}$ average particle size) affecting $12 \mathrm{~h}, \mathrm{Caco}-2$ cells at $2 \mathrm{D}$ cell culture, (f) after $75 \mu \mathrm{g} \mathrm{mL}^{-1} \mathrm{ZnO}$ NPs (24 nm average particle size) affecting $12 \mathrm{~h}$, Caco- 2 cells at 3D cell culture.

inflammatory response which bypassed the increase of ROS levels in 3D cell culture.

When ZnO NPs treatment was extended to $24 \mathrm{~h}$, the levels of IL-8 and IL-1 $\beta$ were further increased in $2 \mathrm{D}$ cell model, whilst decrease of the two protein was observed in $3 \mathrm{D}$ cell model and the levels of IL- 8 were even lower than the basal level of the control groups by $24 \mathrm{~nm} \mathrm{ZnO} \mathrm{NP}$ (the average particle size) at $100 \mu \mathrm{g} \mathrm{mL} \mathrm{m}^{-1}$ (Fig. 4b). $24 \mathrm{~nm}$ ZnO NPs (the average particle size) exposure increased higher levels of IL-8 and IL-1 $\beta$ than $87 \mathrm{~nm}$ ZnO NPs (the average particle size) in 2D cell model, however, less levels of IL-8 than $87 \mathrm{~nm}$ ZnO NPs (the average particle size) in $3 \mathrm{D}$ culture at $24 \mathrm{~h}$ (Fig. $4 \mathrm{~b}, \mathrm{~d}, \mathrm{f}$ and $\mathrm{g}$ ).

\subsection{Cell proliferation}

Fig. 5 showed the changes in DNA quantity (cell proliferation) in the $2 \mathrm{D}$ and $3 \mathrm{D}$ cell model, with $24 \mathrm{~nm} \mathrm{ZnO}$ NPs (the average
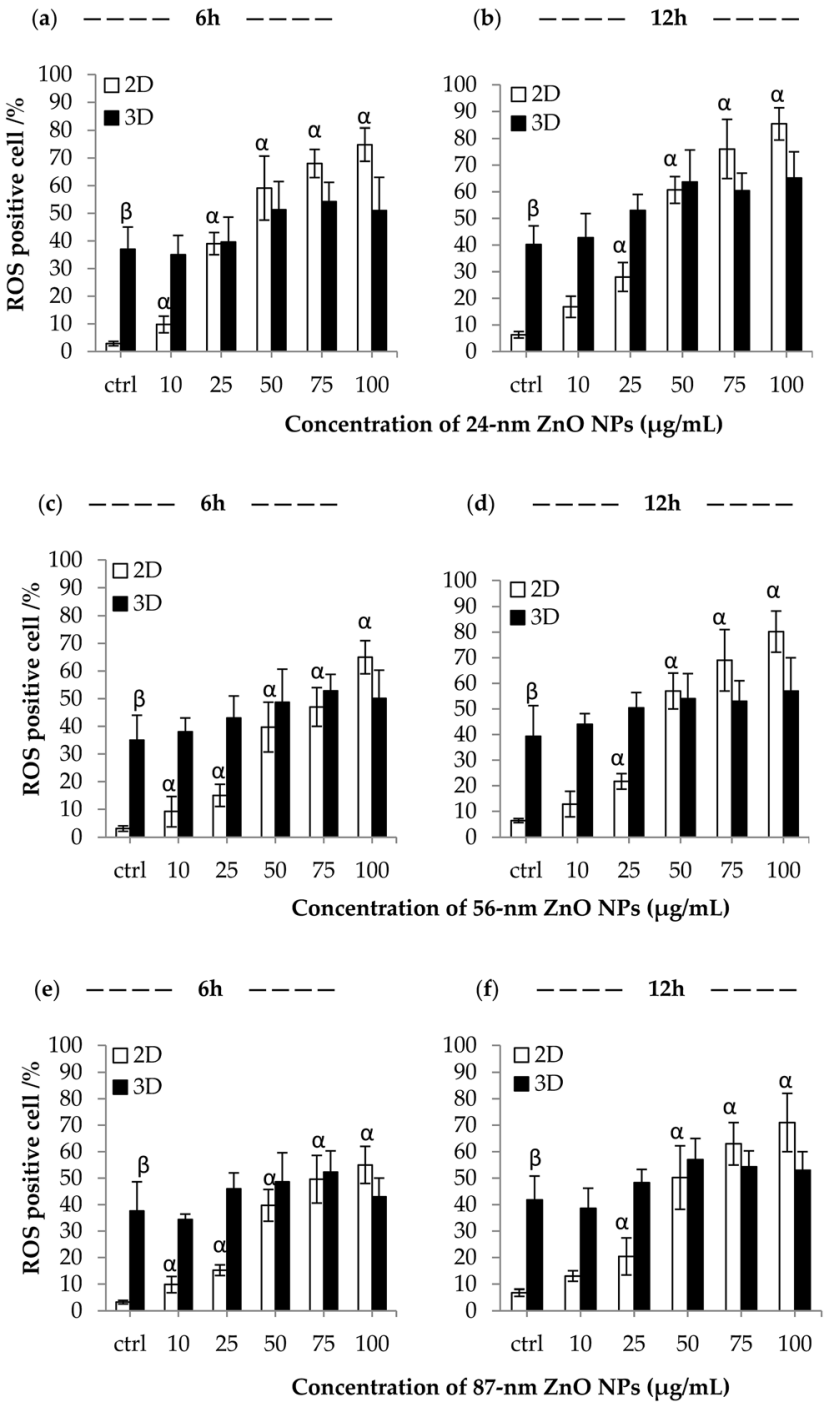

Fig. 3 Intracellular ROS levels to ZnO NPs exposure in 2D and 3D cell model. ROS-positive cells of 2D and 3D cells were observed with various $\mathrm{ZnO}$ NP concentrations after exposure to (a) $24 \mathrm{~nm} \mathrm{ZnO} N P s$ (the average particle size) at $6 \mathrm{~h}$, (b) $24 \mathrm{~nm} \mathrm{ZnO}$ NPs (the average particle size) at $12 \mathrm{~h}$, (c) $56 \mathrm{~nm}$ ZnO NPs (the average particle size) at $6 \mathrm{~h}$, (d) $56 \mathrm{~nm}$ ZnO NPs (the average particle size) at $12 \mathrm{~h}$, (e) $87 \mathrm{~nm}$ ZnO NPs (the average particle size) at $6 \mathrm{~h}$, (f) $87 \mathrm{~nm}$ ZnO NPs (the average particle size) at $12 \mathrm{~h}$. Data represent mean $\pm \mathrm{SE}, n=3 . p<$ $0.05, \beta$ significantly different between the two control groups, $\alpha$ significantly different from control group (ctrl).

particle size) at various concentrations $(0,10,25,50,75$, or 100 $\mu \mathrm{g} \mathrm{mL} \mathrm{m}^{-1}$ ) after 12 and $24 \mathrm{~h}$ of exposure. In $2 \mathrm{D}$ cell model, the amount of DNA was decreased $(p<0.05)$ at various concentrations of ZnO NPs in a dose-dependent manner, especially the amount significantly decreased $(p<0.05)$ onset at $75 \mu \mathrm{g} \mathrm{mL} \mathrm{m}^{-1}$ of $\mathrm{ZnO}$ NPs at $12 \mathrm{~h}$ and $50 \mu \mathrm{g} \mathrm{mL} \mathrm{m}^{-1}$ of ZnO NPs at $24 \mathrm{~h}$ as compared to the $0 \mu \mathrm{g} \mathrm{mL}^{-1} \mathrm{ZnO}$ NPs control. As shown in Fig. 5a, there were no significant differences in the amount of DNA $(p>0.05)$ among various concentrations of ZnO NPs after $12 \mathrm{~h}$ of exposure in 3D cell model. The DNA amounts in the 3D cells incubated with low concentrations of ZnO NPs (below 50 $\mu \mathrm{g} \mathrm{mL}^{-1}$ ) were similar to the control, but incubated with high 

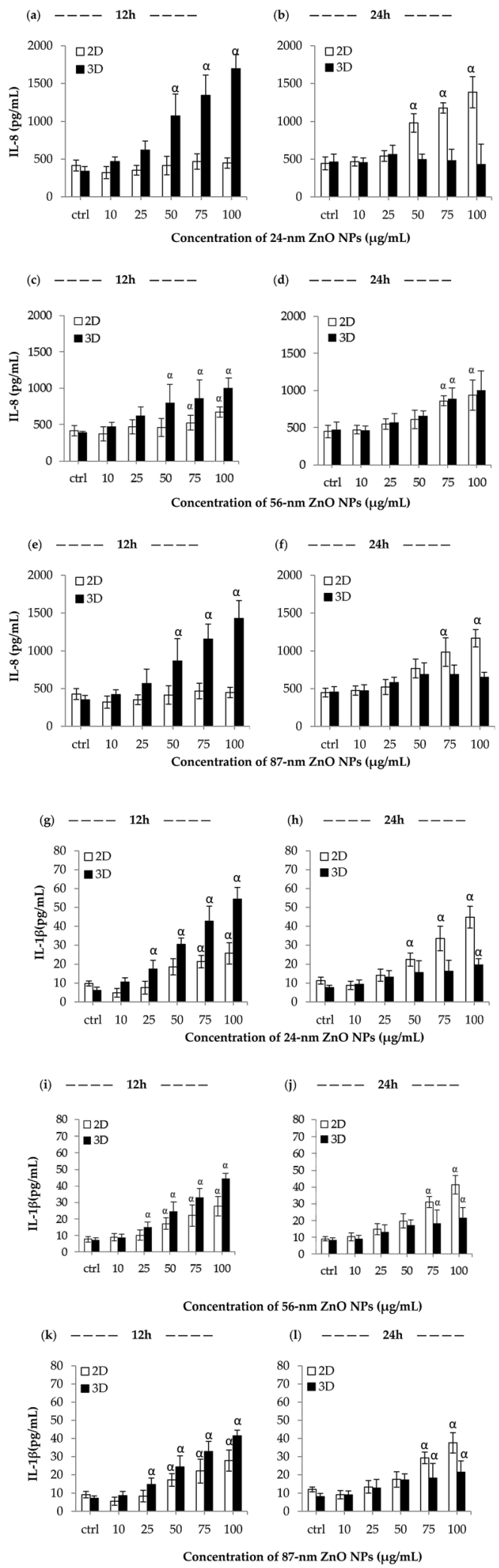

Fig. $4 \mathrm{IL}-8$ and IL-1 $\beta$ expression of $2 \mathrm{D}$ and $3 \mathrm{D}$ cells after exposure to $\mathrm{ZnO}$ NPs. Levels of IL-8 of $2 \mathrm{D}$ and $3 \mathrm{D}$ cells with various $\mathrm{ZnO} N P$ concentrations after exposure to $24 \mathrm{~nm} Z \mathrm{nO} N P s$ (the average particle size) at (a) $12 \mathrm{~h}$, or (b) $24 \mathrm{~h}, 56 \mathrm{~nm}$ ZnO NPs (the average particle size) at (c) $12 \mathrm{~h}$, or (d) $24 \mathrm{~h}$, and $87 \mathrm{~nm} \mathrm{ZnO} N P s$ (the average particle size) at (e) $12 \mathrm{~h}$, or (f) $24 \mathrm{~h}$. Levels of IL-1 $\beta$ of $2 \mathrm{D}$ and 3D cells after exposure to $24 \mathrm{~nm}$ ZnO NPs (the average particle size) at (g) $12 \mathrm{~h}$, or (h) $24 \mathrm{~h}, 56 \mathrm{~nm}$ concentrations of ZnO NPs (75 and $100 \mu \mathrm{g} \mathrm{mL} \mathrm{mL}^{-1}$ ) decreased as compared to the control after $12 \mathrm{~h}$ of exposure (Fig. 5a). Upon $24 \mathrm{~h}$ of ZnO NPs treatment, the amount of DNA was significantly decreased at the highest concentration of ZnO NPs $(100 \mu \mathrm{g}$ $\mathrm{mL}^{-1}$ ) in $3 \mathrm{D}$ cell model, but at $50 \mu \mathrm{g} \mathrm{mL}^{-1}$ of $\mathrm{ZnO}$ NPs in $2 \mathrm{D}$ cell model (Fig. 5b).

\subsection{Modes of cell death}

As shown in Fig. 6, Annexin V-FITC/PI assay captured the different cell death profile in $2 \mathrm{D}$ and $3 \mathrm{D}$ cell model, and implied that Caco-2 cells responded to ZnO NPs toxicity in a dosedependent manner, regardless of the cell model used after $24 \mathrm{~h}$ of treatment. However, higher cell death was observed in $2 \mathrm{D}$ cell model as compare to 3D cell model. $24 \mathrm{~nm} \mathrm{ZnO}$ NPs (the average particle size) exposure increased higher levels of cytotoxicity than $87 \mathrm{~nm}$ ZnO NPs (the average particle size) in 2D cell model, but both were similar levels in 3D culture. Almost no early apoptotic cells were observed in the 2D model onset at 75 $\mu \mathrm{g} \mathrm{mL}{ }^{-1}$ of $24 \mathrm{~nm} \mathrm{ZnO} \mathrm{NPs} \mathrm{(the} \mathrm{average} \mathrm{particle} \mathrm{size)} \mathrm{and} 100 \mu \mathrm{g}$ $\mathrm{mL}^{-1}$ of $87 \mathrm{~nm}$ ZnO NPs (the average particle size) after $24 \mathrm{~h}$ of exposure (Fig. 6a and c). As compared to the control group, 7.1fold and 33-fold increase of late apoptotic and necrotic cells were induced by $100 \mu \mathrm{g} \mathrm{mL} \mathrm{m}^{-1}$ of $24 \mathrm{~nm} \mathrm{ZnO}$ NPs (the average particle size) in 2D cell model, respectively, but 4.2-fold, 12.5fold, and 3.5-fold increase of early apoptotic, late apoptotic, and necrotic cells in $3 \mathrm{D}$ cell culture, respectively (Fig. 6a and b). Cultures exposed to $100 \mu \mathrm{g} \mathrm{mL}^{-1} \mathrm{ZnO}$ NPs showed a severe decrease $(12.9 \%$, and $24.6 \%$ for $24 \mathrm{~nm}$ and $87 \mathrm{~nm} \mathrm{ZnO} \mathrm{NPs} \mathrm{(the}$ average particle size)) in the number of viable $2 \mathrm{D}$ cells when compared with the control (about 95\%), whilst slight decrease (73.9\%, and $75.3 \%$ for $24 \mathrm{~nm}$ and $87 \mathrm{~nm}$ ZnO NPs (the average particle size)) of viable cells in 3D model. After $24 \mathrm{~h}$ of highconcentration $\mathrm{ZnO}$ NPs treatment $\left(75 \mu \mathrm{g} \mathrm{mL}^{-1}\right.$ and $100 \mu \mathrm{g}$ $\mathrm{mL}^{-1}$ ) in the $2 \mathrm{D}$ model, the main mode of cell death is necrosis rather than apoptosis, but there are opposite result was observed at lower concentrations of ZnO NPs (below $50 \mu \mathrm{g}$ $\mathrm{mL}^{-1}$ ) (Fig. 6a and c). In addition, the main mode of cell death observed in the 3D model is also predominantly apoptotic at various concentrations of $\mathrm{ZnO}$ NPs (above $10 \mu \mathrm{g} \mathrm{mL}^{-1}$ ) (Fig. 6b and d).

\section{Discussion}

Caco-2 cell as an in vitro model of the human small intestine mucosa is widely used across the pharmaceutical industry to predict the absorption of orally administered drugs. The cells are approximately 40 to $70 \mu \mathrm{m}$ and spindle-shaped or polygonshaped (high cell density) with adherent cells growing as a confluent monolayer. This study used human colon cell line, since ZnO NMs have been incorporated into some consumer products such as dietary supplements, food additives and food

ZnO NPs (the average particle size) at (i) $12 \mathrm{~h}$, or (j) $24 \mathrm{~h}$, and $87 \mathrm{~nm} \mathrm{ZnO}$ NPs (the average particle size) at (k) $12 \mathrm{~h}$, or (l) $24 \mathrm{~h}$. Values are mean \pm SE from minimum three independent experiments. $p<0.05, \alpha$ significantly different from control group (ctrl). 


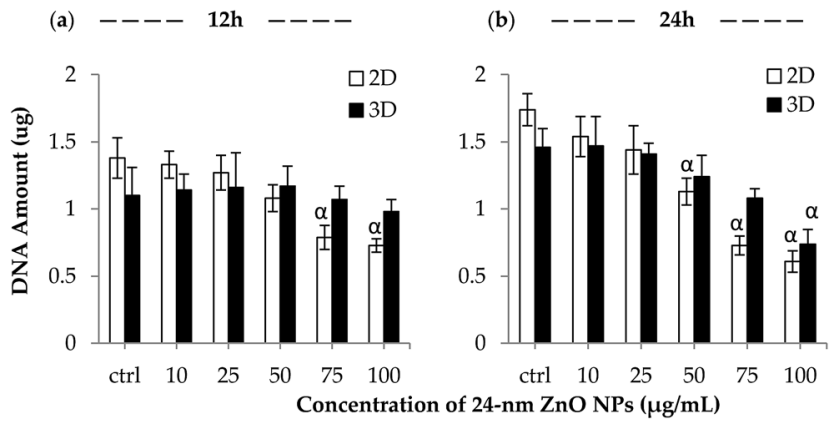

Fig. 5 Changes in DNA levels of 2D and 3D cells with various $\mathrm{ZnO} N P$ concentrations by DNA assay at (a) $12 \mathrm{~h}$ and (b) $24 \mathrm{~h}$. Data represent mean $\pm \mathrm{SE}, n=3$. $p<0.05, \alpha$ significantly different from control group (ctrl).

(a)

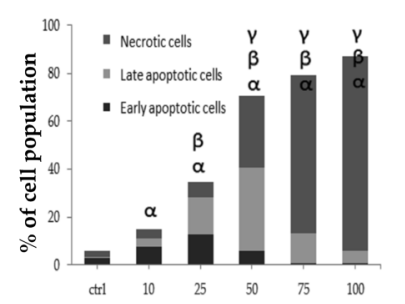

Concentration of 24-nm ZnO NPs $(\mu \mathrm{g} / \mathrm{mL})$

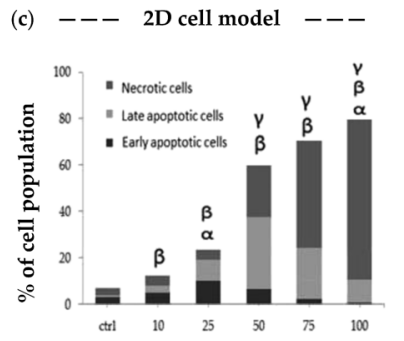

(d)

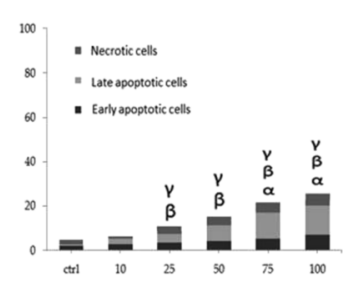

Concentration of 56-nm ZnO NPs $(\mu \mathrm{g} / \mathrm{mL})$

(e)

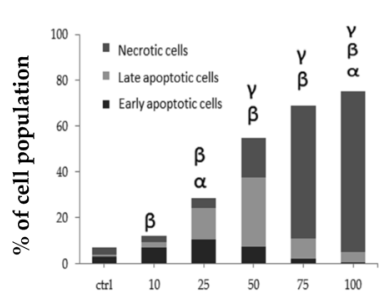

(f)

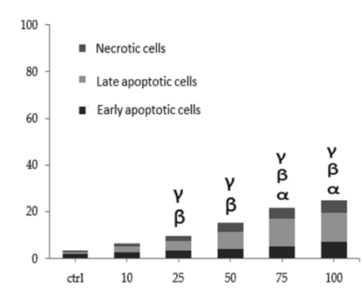

Concentration of 87-nm ZnO NPs $(\mu \mathrm{g} / \mathrm{mL})$

Fig. 6 Quantitative apoptotic measurement of 2D and 3D cells induced by ZnO NPs for $24 \mathrm{~h}$. Different modes of cell death were induced by $24 \mathrm{~nm}$ ZnO NPs (the average particle size) in (a) 2D cell model and (b) 3D cell model, $56 \mathrm{~nm}$ ZnO NPs (the average particle size) in (c) 2D cell model, (d) 3D cell model. $p<0.05,87 \mathrm{~nm}$ ZnO NPs (the average particle size) in (e) 2D cell model, (f) 3D cell model. $p<0.05$, $\alpha$ significantly different with the percentage of early apoptotic cells in control group (ctrl), $\beta$ significantly different with the percentage of late apoptotic cells in ctrl, $\gamma$ significantly different with the percentage of necrotic cells in ctrl. packaging. ${ }^{35}$ The primary objective of this work was aimed at assessing the impact of different-sized ZnO NPs on Caco-2 cell toxicity and inflammatory response among different concentrations in $2 \mathrm{D}$ and $3 \mathrm{D}$ culture environment, in turn re-evaluate their perceived high toxicity of ZnO NPs based on 2D cell model.

Previous studies reported that in vivo cancerous cells could utilize ROS as a signaling molecule to promote their cell proliferation and metastasis. ${ }^{36,37}$ Our observation was consistent with this notion, similarly showed that the 3D cells displayed higher levels of basal ROS as compared to the 2D cells. Fig. 3 indicated that the cells in 3D culture could replicate this in vivo characteristic, while the high ROS characteristics dissipated when the cells were cultured in $2 \mathrm{D}$ format. The percentages of $2 \mathrm{D}$ cells with cytoplasmic ROS levels increase in a timedependent and dose-dependent manner to ZnO NPs exposure, but no significant elevation of ROS was observed in 3D cell model in the time and concentration studied. Similar 2D findings were reported by Kang et al., who suggested that ZnO NPs induced oxidative stress in a dose-dependent manner. ${ }^{30} \mathrm{ZnO}$ NP-induced differential expression of intracellular ROS levels in 2D and 3D cell model indicated that the cellular responses to ZnO NPs were dependent on the cell culture systems. On the other hand, further studies involving downstream events of oxidative stress are needed to explore the underlying toxicity mechanism of ZnO NPs in 2D and 3D cell model. Downstream events of ROS include inflammatory response, ${ }^{38,39}$ membrane damage, ${ }^{40}$ DNA damage, ${ }^{41}$ and these downstream damages can induce cell death. ${ }^{42,43}$

The production of IL-8 and IL-1 $\beta$ induced significant effects on the transcriptional and post-translational levels as they broadly affect inflammatory response. ${ }^{44}$ After $12 \mathrm{~h}$ of highconcentrations ZnO NPs (above $50 \mu \mathrm{g} \mathrm{mL}{ }^{-1}$ ) exposure, the levels of IL-8 and IL-1 $\beta$ protein were significantly increased in 2D and 3D cell model except 2D cells for IL-8 (Fig. 4). The levels of IL-8 and IL- $1 \beta$ were further increased in $2 \mathrm{D}$ cell model, whilst decrease of the two proteins was observed in 3D cell model and the levels of IL- 8 were even lower than the basal level of the control groups by $24 \mathrm{~nm} \mathrm{ZnO} \mathrm{NP}$ at $100 \mu \mathrm{g} \mathrm{mL} \mathrm{mL}^{-1}$ for $24 \mathrm{~h}$. These results indicated that ZnO NPs induced a chronic inflammatory response in $2 \mathrm{D}$ cell culture but acute inflammatory response in 3D cell culture. $24 \mathrm{~nm}$ ZnO NPs exposure increased highest levels of the two proteins in 2D cell model, but less levels of IL-8 than $87 \mathrm{~nm}$ ZnO NPs in 3D culture at $24 \mathrm{~h}$. Expression of proinflammatory cytokines is not highly influenced by particle size in 3D cell model. Therefore, cellular microenvironment can dramatically affect the cellular responses to NMs. ZnO NPs induced inflammatory responses which is independent of ROS levels. ZnO NPs in 2D and 3D cell culture could induce undesirable intracellular ROS, inflammatory responses in preceding sections. At the same time, we further explored whether $\mathrm{ZnO}$ NPs also induce different effects on cell proliferation in 2D and $3 \mathrm{D}$ cell culture.

In Fig. 5, the DNA amounts of $2 \mathrm{D}$ cells were decreased at various concentrations of ZnO NPs in a dose-dependent manner. Interestingly, there were no significant differences in the DNA amounts of 2D cells among various concentrations of ZnO NPs at $12 \mathrm{~h}$, but the amount of DNA was significantly 
decreased since $100 \mu \mathrm{g} \mathrm{mL} \mathrm{mL}^{-1}$ of ZnO NPs in 3D cell model, and since $50 \mu \mathrm{g} \mathrm{mL}{ }^{-1}$ of ZnO NPs in 2D cell model (Fig. 5b). This result showed that Caco- 2 cells in $3 \mathrm{D}$ culture could tolerate a higher concentration of ZnO NPs than the cells in 2D culture. In addition, the $2 \mathrm{D}$ cells displayed higher levels of cell proliferation as compared to the $3 \mathrm{D}$ counterpart between the control groups at 12 and $24 \mathrm{~h}$, indicating that the 2D cells divided more actively than the $3 \mathrm{D}$ cells. However, it raises a concern about long term exposure to ZnO NPs can lead to accumulation of cell damage, as severe decrease of the DNA amounts were detected in 3D model after $24 \mathrm{~h}$ of exposure. To get more clues about the toxicity mechanism of ZnO NPs, we next profiled and quantified the mode of cell death (apoptosis and necrosis) for 2D and 3D cells exposure to ZnO NPs.

Fig. 6 showed 3D cells have a reduced response to the toxicity of $\mathrm{ZnO} \mathrm{NMs}$ as compare to $2 \mathrm{D}$ cells, but two types of cells responded to ZnO NP toxicity in a dose-dependent manner after $24 \mathrm{~h}$ of exposure. ZnO NPs exposure has a particle size effect on $2 \mathrm{D}$ cells, but no difference in 3D model. The main mode of cell death was necrosis rather than apoptosis in the $2 \mathrm{D}$ model, whilst was predominantly apoptotic in the $3 \mathrm{D}$ model. Because $\mathrm{ZnO} \mathrm{NMs}$ are a relatively harder material than the cell membrane, can eventually lead to cell necrotic death as the accumulation of the NMs impacted and damaged the membrane integrity. ${ }^{45}$ A higher exposed area to the accumulated NPs lead to more necrosis as the 2D cell has more spreadout and squamous-type morphology than Caco-2 cell in 3D culture.

In the present study, ZnO NP-induced differential the results of previously described assays indicated that the significant effects of cell-culture models to cellular responses. Actively proliferating cells were previously reported to be more susceptible to certain drugs than quiescent cells. ${ }^{46}$ The same might occur for interactions between cells and ZnO NPs. The 2D cells were more actively dividing as previously described results in Fig. 5, so they tend to take in more nutrients from their surroundings and in turn absorb more ZnO NPs. All in all, the toxic effects of ZnO NPs might be overestimated from the nanotoxicity results of $2 \mathrm{D}$ cell, at least in this study. May is the interaction between cells and cell matrix, have led to this result. Consistent with this result, previous studies similarly showed that the $2 \mathrm{D}$ cell culture overestimate the toxicity of test substances. ${ }^{47,48}$

\section{Conclusions}

In summary, the toxicity of $\mathrm{ZnO}$ NPs on Caco- 2 cells in $3 \mathrm{D}$ model was as follows; accumulated ZnO NPs in the cells elevated intracellular ROS expression inconspicuously, induced acute inflammatory response, significantly decreased the DNA amounts only at high concentrations and induced the toxicity independent of particle size. These events could eventually lead to cell apoptosis rather than cell necrosis. Interestingly, an opposite toxic mechanism of ZnO NPs was observed in our 2D cell model. This study suggested that understanding on how ZnO NPs induced different effects on Caco-2 cells under the simulated in vivo circumstance is very important, and acted as a precursor to other interesting experiments involving other
NMs and 3D models. Caco-2 cells as intestinal epithelial cells would secrete mucin. The mucin secretion between 2D and 3D culture may be different, which could, in turn, causes different toxicity profiles. In the future, it is also necessary to study regarding mechanisms of cytotoxicity due to $\mathrm{ZnO}$ NPs in accordance with the cell types.

\section{Author contributions}

Zhipan Wu, Miao Tao, Rongfa Guan, Fei Lyu, and Mingqi Liu conceived and designed the experiments; Zhipan Wu and Miao Tao performed the experiments; Rongfa Guan, Fei Lyu, Guozhou Cao, and Jianguo Gao analyzed the data; Rongfa Guan wrote the paper.

\section{Conflicts of Interest}

The authors declare no competing financial interest.

\section{Abbreviations}

$\begin{array}{ll}\text { ZnO NPs } & \text { Zinc oxide nanoparticles } \\ \text { ROS } & \text { Reactive oxygen species } \\ \text { PI } & \text { Propidium iodide } \\ \text { VA } & \text { Early apoptotic cell } \\ \text { NVA } & \text { Late apoptotic cell } \\ \text { NVN } & \text { Necrotic cell }\end{array}$

\section{Acknowledgements}

We wish to thank all members of the Zn-NPs team, supported by Zhejiang Provincial Key Laboratory of Biometrology and Inspection \& Quarantine. We gratefully acknowledged financial support from General Administration of Quality Supervision, Inspection and Quarantine of the People's Republic of China (201410083), National Natural Science Foundation of China (31571845), Zhejiang Provincial Public Technology Application Research Project (2015C32023) and Zhejiang Provincial Natural Science Foundation of China (LY14C200012).

\section{References}

1 A. E. Nel, L. Mädler, D. Velegol, T. Xia, E. M. Hoek, P. Somasundaran, F. Klaessig, V. Castranova and M. Thompson, Nat. Mater., 2009, 8, 543-557.

2 A. Nel, T. Xia, L. Mädler and N. Li, Science, 2006, 311, 622627.

3 M. A. Dobrovolskaia and S. E. McNeil, Nat. Nanotechnol., 2007, 2, 469-478.

4 G. Veronesi, A. Deniaud, T. Gallon, P. H. Jouneau, J. Villanova, P. Delangle, M. Carriere, I. Kieffer, P. Charbonnier, E. Mintz and I. Michaud-Soret, Nanoscale, 2016, 8, 17012-17021.

5 C. Y. Tay, M. I. Setyawati, J. Xie, W. J. Parak and D. T. Leong, Adv. Funct. Mater., 2014, 24, 5936-5955.

6 S. L. Chia and D. T. Leong, Heliyon, 2016, 2, e00177. 
7 Y. Gong, Y. Ji, F. Liu, J. Li and Y. Cao, J. Appl. Toxicol., 2016, DOI: $10.1002 /$ jat.3415.

8 G. D. Venkatasubbu, R. Baskar, T. Anusuya, C. A. Seshan and R. Chelliah, Colloids Surf., B, 2016, 148, 600-606.

9 M. Chevallet, B. Gallet, A. Fuchs, P. H. Jouneau, K. Um, E. Mintz and I. Michaud-Soret, Nanoscale, 2016, 8, 18495-18506.

10 H. Page, P. Flood and E. G. Reynaud, Cell Tissue Res., 2013, 352, 123-131.

11 D. W. Hutmacher, Nat. Mater., 2010, 9, 90-93.

12 J. Lee, M. J. Cuddihy and N. A. Kotov, Tissue Eng., Part B, 2008, 14, 61-86.

13 L. G. Griffith and M. A. Swartz, Nat. Rev. Mol. Cell Biol., 2006, 7, 211-224.

14 S. L. Chia, C. Y. Tay, M. I. Setyawati and D. T. Leong, Small, 2016, 12, 647-657.

15 M. Lutolf and J. Hubbell, Nat. Biotechnol., 2005, 23, 47-55.

16 C. Y. Tay, M. S. Muthu, S. L. Chia, K. T. Nguyen, S. S. Feng and D. T. Leong, Adv. Funct. Mater., 2016, 26, 4046-4065.

17 B. Feigl and D. Hutmacher, Adv. Healthcare Mater., 2013, 2, 1056-1062.

18 M. J. Bissell, A. Rizki and I. S. Mian, Curr. Opin. Cell Biol., 2003, 15, 753.

19 S. L. Chia, C. Y. Tay, M. I. Setyawati and D. T. Leong, Small, 2015, 11, 702-712.

20 C. M. Sayes, K. L. Reed and D. B. Warheit, Toxicol. Sci., 2007, 97, 163-180.

21 T. R. Pisanic, J. D. Blackwell, V. I. Shubayev, R. R. Fiñones and S. Jin, Biomaterials, 2007, 28, 2572-2581.

22 A. Magrez, S. Kasas, V. Salicio, N. Pasquier, J. W. Seo, M. Celio, S. Catsicas, B. Schwaller and L. Forró, Nano Lett., 2006, 6, 1121-1125.

23 C. M. Sayes, J. D. Fortner, W. Guo, D. Lyon, A. M. Boyd, K. D. Ausman, Y. J. Tao, B. Sitharaman, L. J. Wilson and J. B. Hughes, Nano Lett., 2004, 4, 1881-1887.

24 Y. Zhang, W. Chen, J. Zhang, J. Liu, G. Chen and C. Pope, J. Nanosci. Nanotechnol., 2007, 7, 497-503.

25 C. M. Sayes, A. A. Marchione, K. L. Reed and D. B. Warheit, Nano Lett., 2007, 7, 2399-2406.

26 Z. Liu, C. Davis, W. Cai, L. He, X. Chen and H. Dai, Proc. Natl. Acad. Sci. U. S. A., 2008, 105, 1410-1415.

27 K. M. Yamada and E. Cukierman, Cell, 2007, 130, 601-610.

28 F. Pampaloni, E. G. Reynaud and E. H. Stelzer, Nat. Rev. Mol. Cell Biol., 2007, 8, 839-845.

29 D. M. Bryant and K. E. Mostov, Nat. Rev. Mol. Cell Biol., 2008, 9, 887-901.
30 T. Kang, R. Guan, X. Chen, Y. Song, H. Jiang and J. Zhao, Nanoscale Res. Lett., 2013, 8, 1-8.

31 R. Mauck, X. Yuan and R. Tuan, Osteoarthritis Cartilage, 2006, 14, 179-189.

32 M. H. Wu, J. P. Urban, Z. F. Cui, Z. Cui and X. Xu, Biotechnol. Prog., 2007, 23, 430-434.

33 C. Monteiller, L. Tran, W. MacNee, S. Faux, A. Jones, B. Miller and K. Donaldson, Occup. Environ. Med., 2007, 64, 609-615.

34 W. C. Cho and K. N. Leung, Cancer Lett., 2007, 252, 43-54.

35 D. Loessner, S. C. Rizzi, K. S. Stok, T. Fuehrmann, B. Hollier, V. Magdolen, D. W. Hutmacher and J. A. Clements, Biomaterials, 2013, 34, 7389-7400.

36 S. L. Payne, B. Fogelgren, A. R. Hess, E. A. Seftor, E. L. Wiley, S. F. Fong, K. Csiszar, M. J. Hendrix and D. A. Kirschmann, Cancer Res., 2005, 65, 11429-11436.

37 J. P. Fruehauf and F. L. Meyskens, Clin. Cancer Res., 2007, 13, 789-794.

38 M. Giovanni, C. Y. Tay, M. I. Setyawati, J. Xie, C. N. Ong, R. Fan, J. Yue, L. Zhang and D. T. Leong, Environ. Toxicol., 2015, 30, 1459-1469.

39 X. Cheng, W. Zhang, Y. Ji, J. Meng, H. Guo, J. Liu, X. Wu and H. Xu, RSC Adv., 2013, 3, 2296-2305.

40 W. Lin, Y. Xu, C. C. Huang, Y. Ma, K. B. Shannon, D. R. Chen and Y. W. Huang, J. Nanopart. Res., 2009, 11, 25-39.

41 V. Sharma, D. Anderson and A. Dhawan, J. Biomed. Nanotechnol., 2011, 7, 98-99.

42 M. I. Setyawati, C. Y. Tay and D. T. Leong, Biomaterials, 2013, 34, 10133-10142.

43 M. I. Setyawati, X. Yuan, J. Xie and D. T. Leong, Biomaterials, 2014, 35, 6707-6715.

44 T. Strowig, J. Henao-Mejia, E. Elinav and R. Flavell, Nature, 2012, 481, 278-286.

45 G. DeLoid, J. M. Cohen, T. Darrah, R. Derk, L. Rojanasakul, G. Pyrgiotakis, W. Wohlleben and P. Demokritou, Nat. Commun., 2014, 5, 3514.

46 R. Schulz, F. Streller, A. Scheel, J. Rüschoff, M. Reinert, M. Dobbelstein, N. Marchenko and U. Moll, Cell Death Dis., 2014, 5, e980.

47 U. G. Sauer, S. Vogel, A. Hess, S. N. Kolle, L. Ma-Hock, B. van Ravenzwaay and R. Landsiedel, Toxicol. In Vitro, 2013, 27, 174-190.

48 W. S. Cho, R. Duffin, M. Bradley, I. L. Megson, W. MacNee, J. K. Lee, J. Jeong and K. Donaldson, Part. Fibre Toxicol., 2013, 10, 1. 